mind the trend towards increase of consumption as well as the trend of the population". It is shown in the leading article of this issue of NATURE that this view of the situation is quite inadequate, and that something much more fundamental and drastic is required to meet the ever-increasing demands on the water resources of the country. Sir Hilton closes his contribution with a note on rural supplies in which he says that schemes costing a million sterling are "already in sight" and many more schemes are on the way.

\section{Water Resources and their Administration}

IN a succeeding article on "National Water Resources and the Need for a Comprehensive Survey", Mr. R. B. Dunwoody takes a much sounder and more practical view of the matter, recalling the investigation of the Royal Commission (1906-1911) on Canals and Waterways, which showed "a striking absence of statistical information as to the flows of rivers and streams, and consequently of the water available in different parts of the country". On the completion of the investigation, as secretary of the Commission, he submitted in 1911 to the President of the Local Government Board a scheme for a comprehensive survey of the water supplies of England and Wales. Considerable extracts are quoted from the memorandum, all indicating that it has much in common with the proposals for a survey now being urged on the Government. Mr. Clemesha Smith, in his article on "Regional Water Supplies", presses the need for co-ordination. Amplifying the policy of the appointment in several parts of the country of regional advisory committees, he considers that committees in respect of suitable areas should be set up covering the whole of England and Wales. He outlines the functions of the two sets of bodies he proposes, as follows: (a) regional committees, consisting of representatives of authorities, charged with the duty of supplying water for domestic purposes, empowered to demand the necessary information and able to raise funds to enable them to check statistics and examine and put forward proposals relating to water supply; and (b) water commissions, the duties of which should include considering the tabulated statistics prepared by the regional committees and advising them on the schemes submitted and as to improvements, amalgamations and variations. Mr. Smith emphasises that if problems of water supply are to be solved on rational lines, the first step must be the accumulation of accurate information, and the second the examination and consideration of the facts by recognised authorities.

\section{The 24-Hour Time System}

ThE question of the 24-hour time system was raised in the House of Lords on July 27 by an inquiry from Lord Lamington whether a report on the working of this system by the British Broadcasting Corporation would be laid on the table of the House. Lord Templemore, speaking for the Government, said that no formal report has yet been received from the Corporation, but the Postmaster-General understands that the Corporation will, before very long, make a statement on the subject. In the light of information given by the Corporation, the Government has had under consideration the question of extending the use of the 24-hour method of expressing time. Lord Templemore added that he was authorised to say that the Government, after carefully reviewing the whole question of adopting the 24-hour notation for official purposes, has come to the conclusion that there is still no sufficient evidence of a general public demand for any change to justify it in taking any action in the matter.

\section{The British Broadcasting Corporation Experiment}

THE B.B.C. has stated that there has been no evidence of either widespread opposition or support to the experimental use by it of the 24-hour system. An announcement will be made in due course to what extent, if at all, it will continue the use of the system for other than internal purposes. The experiment was intended to familiarise the public with the 24-hour notation, but has been widely misrepresented in a certain section of the Press as an attempt to impose the 24-hour system for the purposes of everyday life. One paper published photographs of the well-known 24-hour clock at the gate of Greenwich Observatory, and of an ordinary 12-hour dial, and held what was stated to be a plebiscite on the question of the 24-hour system. The voting paper required a cross to be placed against whichever dial was preferred, and the result was announced as a large majority against the 24-hour system. An inereasing number of engineering, electrical and other organisations, which are in continuous operation by day and by night, are using the 24-hour system owing to its conveniences and no difficulties of any sort have arisen from its use. The use of the system by the B.B.C. should have educated the public sufficiently for time-tables using the 24-hour notation to be understood. It is to be hoped that the railway companies and road transport organisations will not wait any longer for a Government lead, but that they will introduce the 24-hour system in their timetables by mutual agreement.

\section{Scientific Research on Works of Art}

THE forthcoming academic year will witness an important new development at the Courtauld Institute of Art, University of London. Since its inception, the Institute, which is under the directorship of Prof. W. G. Constable, has recognised the necessity for systematic and scientific research into the physical constitution of works of art : and a new Department and Laboratory of Scientific Research has now been brought into being at the Institute, at which such lines of investigation will be actively pursued. Such problems as the nature of the changes undergone by works of art on cleaning and renovation, and on exposure to atroospheric moisture and light, and the advantages of different methods of treating 'diseases' of works of art, will receive systematic investigation. So far, work in Great Britain has been carried out for the most part 
by private investigators, though various laboratories abroad, such as those at the Fogg Art Museum, Harvard University, and at the Technical High School, Munich, have attacked the subject systematically. One of the main aims of the new Department will be the co-ordination of its results, with the view of publication, with these obtained in other centres, with which close relations will be cultivated. The head of the new Department and Laboratory is Dr. P. D. Ritchie, who will have the benefit of the knowledge and experience of a permanent advisory committee consisting of a number of prominent men of science and art experts. It is hoped that the Department will be in active operation by October, though no problems can be dealt with before that date.

\section{International Anthropology and Ethnology}

THE first session of the International Congress of Anthropological and Ethnological Sciences was opened by H.R.H. Prince George at University College, London, on July 30. The Congress is the outcome of a movement initiated more than twenty years ago, when in 1912, after the London Meeting of the International Congress of Americanists, a small international committee was appointed by the Royal Anthropological Institute to organise such a Congress. As a result of no little negotiation and correspondence, it was then arranged that a Congress should take place in 1916. Owing to the War, the Congress did not meet, and the proposal fell into abeyance, until in the course of the discussion of arrangements for the International Congress of Prehistoric and Protohistoric Sciences, which met in London in 1932, it emerged that the need for an international meeting ground for the discussion of the problems of ethnology was urgently felt. Experience gained by the inclusion of an ethnological section at the archæological congresses organised after the War by the French Institut d'Anthropologie had proved to the satisfaction of most of those who had taken part that nothing short of an independent congress would prove satisfactory. Many, with good reason, were reluctant to add to the already large number of international scientific congresses; but the almost overwhelmingly heavy programme submitted at this first session is a sufficient proof of the wisdom of the decision. Not merely the number and the variety of the communications, but also the number of joint diseussions between two or more sections-thirteen discussions in all-shows that, even within the limits laid down by those responsible for the organisation of the programme, the debatable questions in ethnology, which it is felt desirable to ventilate by open discussion, are numerous.

ON the opening, the Congress numbered more than a thousand members, and delegates from no less than forty-two different countries were present when Lord Onslow delivered his presidential address at the inaugural meeting. America, both North and South, was well represented, owing to the approximation of the date to that of the forthcoming European session of the International Congress of Americanists later in the month. This is a coincidence which the promoters had in view as a regular recurrence every four years, when the present year was chosen to initiate the series. As the presence of so many foreign anthropologists of distinction is not likely to occur again for a long time to come, every effort had been made to show them as much as possible of the ethnographical and archæological treasures of our public and private collections, while a number of special exhibits had been arranged. Among these, one of the most striking was the exhibit of material brought back by Miss G. Caton-Thompson and Miss E. W. Gardiner from their investigations on behalf of the Royal Anthropological Institute at El Khargeh in Egypt. The exhibits illustrate the classification of stone implements into seven periods of the Stone Age, the fossil mound springs which have demonstrated the existence of two pluvial periods, and have afforded evidence not only of the character of the water supply but have also provided data bearing on the relation of prehistoric tools to fossil vegetation, of which the exact period and determination had hitherto defeated investigators. This exhibition will be on view to the public after the Congress for a period of three months. The British Museum also arranged an exhibit especially for American visitors, which included the famous Maudslay Maya plaster casts and examples of the antiquities obtained by the Museum's expeditions to British Honduras. Special interest also attached to the prehistoric pottery brought by Sir Aurel Stein from Baluchistan and Persia, in view of the subject of the Huxley Memorial Lecture, which he delivered on July 31, before the Congress.

\section{Exhibits from Tell Duweir, Palestine}

IN order to afford those attending the International Congress of Anthropological Sciences in London an opportunity of viewing the antiquities from Tell Duweir, the Exhibition of the Wellcome Archæological Research Expedition in the rooms of the Palestine Exploration Fund, Manchester Square, remained open until August 3. Much interest was aroused by the exhibits, the inscribed ewer naturally attracting a great deal of attention. Further fragments of the ewer have been found among the material brought from Palestine, and these have added definition to its form, while the line of decora. tion is now almost continuous. A card exhibited with the ewer gave the alternative readings which have been proposed. Even more impressive were the relics from the sanctuary shrine in the fosse, of which the destruction is dated by the Rameses II plaque as not earlier than the first half of the thirteenth century B.C. The preservation in situ, and in some instances intact, of the appointments of the shrine gives the find a unique character. These objects, including the benches for offerings, the libation jar and offerings bin and the like, were displayed in and around a model reconstructed from squeezes. This exact record of a remarkable cult-object reflects the greatest credit on the initiative and technical skill of the members of the expedition. 